\title{
Carboxymethyl Cellulose Entrapped in a Poly(vinyl) Alcohol Network: Plant-Based Scaffolds for Cartilage Tissue Engineering
}

\author{
Jirapat Namkaew ${ }^{1}$, Panitporn Laowpanitchakorn ${ }^{2}$, Nuttapong Sawaddee ${ }^{1}$, Sirinee Jirajessada ${ }^{3}$, \\ Sittisak Honsawek ${ }^{4}\left(\mathbb{D}\right.$ and Supansa Yodmuang ${ }^{5, *}$ (D)
}

check for

updates

Citation: Namkaew, J.;

Laowpanitchakorn, P.; Sawaddee, N.;

Jirajessada, S.; Honsawek, S.;

Yodmuang, S. Carboxymethyl

Cellulose Entrapped in a Poly(vinyl)

Alcohol Network: Plant-Based

Scaffolds for Cartilage Tissue

Engineering. Molecules 2021, 26, 578.

https://doi.org/10.3390/

molecules 26030578

\section{Academic Editor:}

Matthias Schnabelrauch

Received: 24 November 2020

Accepted: 19 January 2021

Published: 22 January 2021

Publisher's Note: MDPI stays neutral with regard to jurisdictional claims in published maps and institutional affiliations.

Copyright: (c) 2021 by the authors. Licensee MDPI, Basel, Switzerland. This article is an open access article distributed under the terms and conditions of the Creative Commons Attribution (CC BY) license (https:/ / creativecommons.org/licenses/by/ $4.0 /)$
1 Excellence Center for Advanced Therapy Medicinal Products, King Chulalongkorn Memorial Hospital, Pathumwan, Bangkok 10330, Thailand; namkaew.j@gmail.com (J.N.); nuttapong_tontoey@hotmail.com (N.S.)

2 Biomaterial Engineering for Medical and Health Research Unit, Chulalongkorn University, Pathumwan, Bangkok 10330, Thailand; antpnp@gmail.com

3 Biology Program, Faculty of Science, Buriram Rajabhat University, Muang, Buriram 31000, Thailand; sirinee.ym@bru.ac.th

4 Osteoarthritis and Musculoskeleton Research Unit, Faculty of Medicine, Chulalongkorn University, Pathumwan, Bangkok 10330, Thailand; sittisak.h@chula.ac.th

5 Research Affairs, Faculty of Medicine, Chulalongkorn University, Pathumwan, Bangkok 10330, Thailand

* Correspondence: supansa.y@chula.ac.th; Tel.: +66-6-3774-8604

\begin{abstract}
Cartilage has a limited inherent healing capacity after injury, due to a lack of direct blood supply and low cell density. Tissue engineering in conjunction with biomaterials holds promise for generating cartilage substitutes that withstand stress in joints. A major challenge of tissue substitution is creating a functional framework to support cartilage tissue formation. Polyvinyl alcohol (PVA) was crosslinked with glutaraldehyde (GA), by varying the mole ratios of GA/PVA in the presence of different amounts of plant-derived carboxymethyl cellulose (CMC). Porous scaffolds were created by the freeze-drying technique. The goal of this study was to investigate how CMC incorporation and crosslinking density might affect scaffold pore formation, swelling behaviors, mechanical properties, and potential use for engineered cartilage. The peak at $1599 \mathrm{~cm}^{-1}$ of the $C=O$ group in ATR-FTIR indicates the incorporation of CMC into the scaffold. The glass transition temperature $\left(\mathrm{T}_{\mathrm{g}}\right)$ and Young's modulus were lower in the PVA/CMC scaffold, as compared to the PVA control scaffold. The addition of CMC modulates the pore architecture and increases the swelling ratio of scaffolds. The toxicity of the scaffolds and cell attachment were tested. The results suggest that PVA/CMC scaffolding material can be tailored in terms of its physical and swelling properties to potentially support cartilage formation.
\end{abstract}

Keywords: poly(vinyl) alcohol; sodium carboxymethyl cellulose; scaffolds; tissue engineering

\section{Introduction}

Articular cartilage is a specialized connective tissue covering the ends of long bones. It has unique viscoelastic properties and exhibits time-dependency in its stress-strain response. It serves as a shock absorber as it is tough but highly deformable and lubricious for low friction. After injury, the dense matrix and poor vascularization of cartilage contribute to the lack of intrinsic repairability by preventing mature chondrocytes or progenitor cells from bone marrow migration to defect areas [1]. Without proper treatment, cartilage defects may progress to osteoarthritis (OA) and eventually require total joint replacement. Although better overall health care is contributing to a steady rise in the number of elderly people worldwide, OA remains a challenge for the elderly, who face limited mobility. Better OA treatment will contribute to improving the quality of life of this elderly population including those who suffer from trauma, sports injuries, and repetitive use of joints [2]. 
The available treatment options for chondral defects include pain medications and arthroscopic surgery, e.g., abrasion, debridement, and microfracture [2]. Despite these promising procedures being minimally invasive, they rarely restore structure and function of injured cartilage to the level of native tissue. Cell-based cartilage tissue repair aims at replacing and regenerating damaged cartilage without complications associated with donor-site morbidity from autografts and the risk of disease transmission or induction of immune response from allografts [3]. Over the past 20 years, researchers have been in search of biomedical polymers in order to construct the template for cell proliferation and tissue development.

Synthetic biomaterials such as polycaprolactone [4], polyvinyl alcohol [5], and polylactic acid [6] have well-defined mechanical and rheological properties and transport of molecules by modulating degree of substitution and crosslinking density [7]. However, these materials are inert and lack biological cues that can promote cell adhesion, proliferation, and chondrogenic differentiation. Natural biomaterials such as collagen [8], silk [9], Matrigel ${ }^{\circledR}$ (Corning, NY, USA) [10], chitosan [11], and hyaluronic acid [12] containing biological cues similar to the extracellular matrix have been used to make scaffolds. Although natural materials are biocompatible and biodegradable, these materials generally have poor mechanical properties and are difficult to handle. Recently, the utilization of renewable resources and eco-friendly materials, especially from plants, has gained increasing attention in medical innovation (cosmetic, foods, drug capsules) $[13,14]$.

The natural polymer of choice in this study is carboxymethyl cellulose (CMC). CMC is a polysaccharide polymer containing hydroxyl groups, which are replaced by sodium carboxymethyl groups in C2, C3, and C6 of glucopyranose [15]. CMC has been widely used as a dispersion agent in the paint industry, a thickener in foods, and a stabilizer in pharmaceutical and medical products [16]. Highly negatively charge from -COOand -O- groups in aqueous solution enables CMC to attract water and create a hydrated environment similar to the extracellular matrix. In order to leverage the use of CMC in cartilage tissue engineering applications, scaffolds made from CMC have to withstand loads in joints after implantation. Combining CMC with more stable and controllable synthetic biomaterials will address the mechanical limitation of the naturally derived polymer and preserve biological properties of CMC in scaffold constructs. Polyvinyl alcohol (PVA) is a hydrophilic synthetic polymer that can be a non-biodegradable polymer after chemical crosslinking. It is biocompatible and has FDA approval for clinical uses, including wound dressing, drug delivery vehicles, and tissue engineering application $[17,18]$.

The objective of this study was to investigate how CMC incorporation and crosslinking density might affect PVA/CMC scaffold formation. We hypothesized that incorporation of CMC increases hydrated environment in scaffolds to promote cell attachment without cytotoxicity. To test this hypothesis, PVA was crosslinked with glutaraldehyde (GA) by varying mole ratios of GA/PVA in the presence of different PVA/CMC mass ratios. Pore architecture, swelling behaviors, and mechanical properties of PVA/CMC porous scaffolds were investigated. The composition and thermal properties of composite scaffolds were characterized by ATR-Fourier transform infrared spectroscopy (ATR-FTIR) and differential scanning calorimetry (DSC), respectively. Chondrocytes were seeded into the scaffold to evaluate cytotoxicity for 7 days. Through this work, we provide valuable insights into the role of synthetically and naturally derived polymers in controlling properties of porous scaffolds. Crosslinking density in conjunction with CMC entrapment can be used to tailor mechanical properties and structure of the scaffold for engineered cartilage.

\section{Results}

\subsection{Appearances of Hydrogels after Fabrication}

PVA/CMC scaffolds were fabricated by combining PVA and CMC at different mass ratios (PVA/CMC). The degree of crosslinking was varied and indicated by the mole ratio of GA and PVA (GA/PVA). The PVA control group, P1C0, was able to form hydrogels in 
all crosslinking ratios, while $\mathrm{P} 5 \mathrm{C} 1$ and $\mathrm{P} 3 \mathrm{C} 1$ groups failed to form hydrogel at crosslinking ratio of 0.05 (Figure 1).

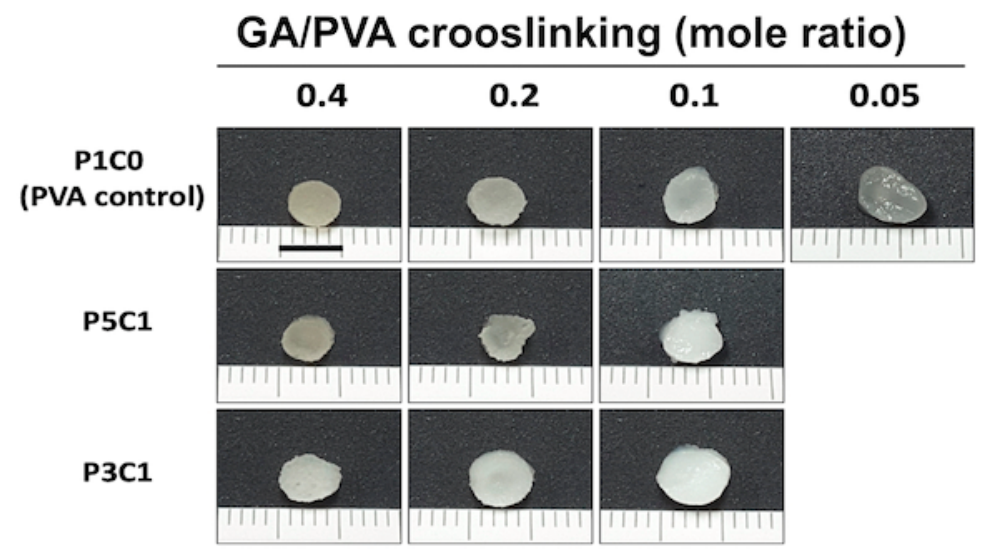

Figure 1. Appearance of PVA/CMC porous scaffolds. $\mathrm{P} 1 \mathrm{C} 0$ is $\mathrm{PVA} / \mathrm{CMC}=1: 0 ; \mathrm{P} 5 \mathrm{C} 1$ is $\mathrm{PVA} / \mathrm{CMC}$ $=5: 1 ; \mathrm{P} 3 \mathrm{C} 1$ is $\mathrm{PVA} / \mathrm{CMC}=3: 1$. The scale bar is $0.5 \mathrm{~cm}$.

\subsection{Fourier Transform Infrared Spectroscopy (FTIR)}

The scaffolds $\mathrm{P} 1 \mathrm{C} 0, \mathrm{P} 5 \mathrm{C} 1$, and $\mathrm{P} 3 \mathrm{C} 1$ at a GA/PVA crosslinking ratio of 0.2 were chosen for ATR-FTIR analysis. FTIR spectra of PVA powder showed the stretching O-H of the hydroxyl group at $3360-3321 \mathrm{~cm}^{-1}$. The $\mathrm{C}=\mathrm{O}$ of acetyl group $\left(1715-1733 \mathrm{~cm}^{-1}\right)$ was observed. These peaks are specific for the remaining acetate groups of polyvinyl acetate, which is a precursor for polyvinyl alcohol production (Figure 2). Crystallinity of PVA before dissolving was clearly observed only in PVA powder at $1140 \mathrm{~cm}^{-1}$. A shift in peak at $1570 \mathrm{~cm}^{-1}$ was observed in P1C0, P5C1, and P3C1 scaffolds, which crosslinked with glutaraldehyde. The peaks at 2851 and $2871 \mathrm{~cm}^{-1}$ indicated that the $\mathrm{C}-\mathrm{H}$ resulted from glutaraldehyde crosslinking in all scaffolds. The major characteristic peak of CMC is the stretching $\mathrm{C}=\mathrm{O}$ of the COONa group at $1592 \mathrm{~cm}^{-1}$, which was shifted to $1599 \mathrm{~cm}^{-1}$, as demonstrated in $\mathrm{P} 5 \mathrm{C} 1$ and $\mathrm{P} 3 \mathrm{C} 1$ groups.

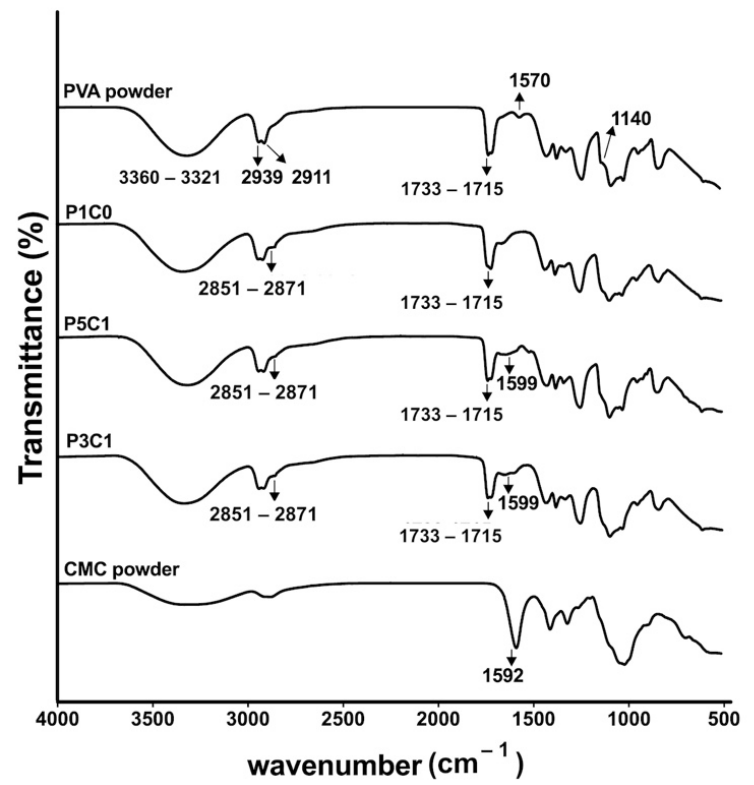

Figure 2. ATR-FTIR analysis of PVA powder, P1C0 PVA control, P5C1 scaffold, P3C1 scaffold, and CMC powder. The representative scaffolds have a GA/PVA crosslinking ratio of 0.2 . P1C0 is $\mathrm{PVA} / \mathrm{CMC}=1: 0 ; \mathrm{P} 5 \mathrm{C} 1$ is $\mathrm{PVA} / \mathrm{CMC}=5: 1 ; \mathrm{P} 3 \mathrm{C} 1$ is $\mathrm{PVA} / \mathrm{CMC}=3: 1$. 


\subsection{Differential Scanning Calorimetry (DSC)}

The thermal properties of scaffolds could be modulated by varying PVA and CMC contents and crosslinking density. The onset of the glass transition temperature $\left(\mathrm{T}_{\mathrm{g}}\right)$ ranged from 70 to $85^{\circ} \mathrm{C}$, as demonstrated by a sudden decrease of the heat flow in the heating curve (Figure $3 \mathrm{~A}$ ). In the P1C0 control group, the GA/PVA crosslinking ratio of 0.4 exhibited higher $\mathrm{T}_{\mathrm{g}}\left(84.2^{\circ} \mathrm{C}\right)$ compared to other crosslinking ratios $\left(78.1^{\circ} \mathrm{C}\right.$ for GA/PVA $=0.2$ and $72.0^{\circ} \mathrm{C}$ for $\left.\mathrm{GA} / \mathrm{PVA}=0.1\right)$. When $\mathrm{CMC}$ was incorporated into scaffolds, a slight decrease in $\mathrm{T}_{\mathrm{g}}$ was detected in $\mathrm{P} 5 \mathrm{C} 1$ and $\mathrm{P} 3 \mathrm{C} 1$ groups.

A

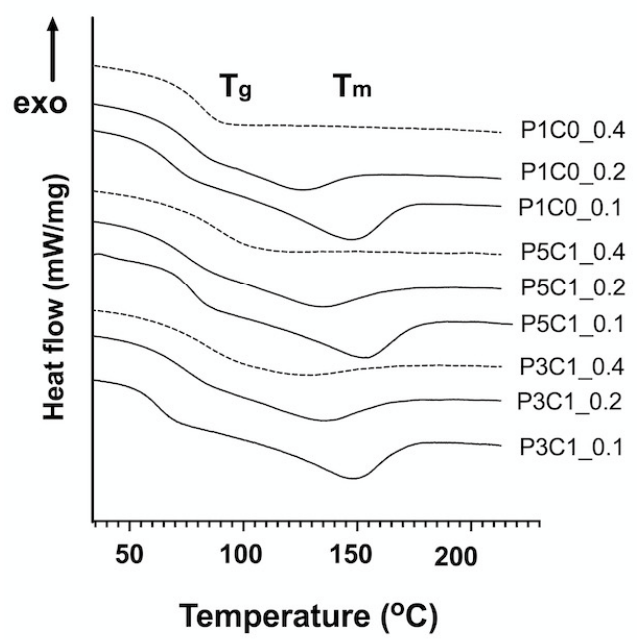

B

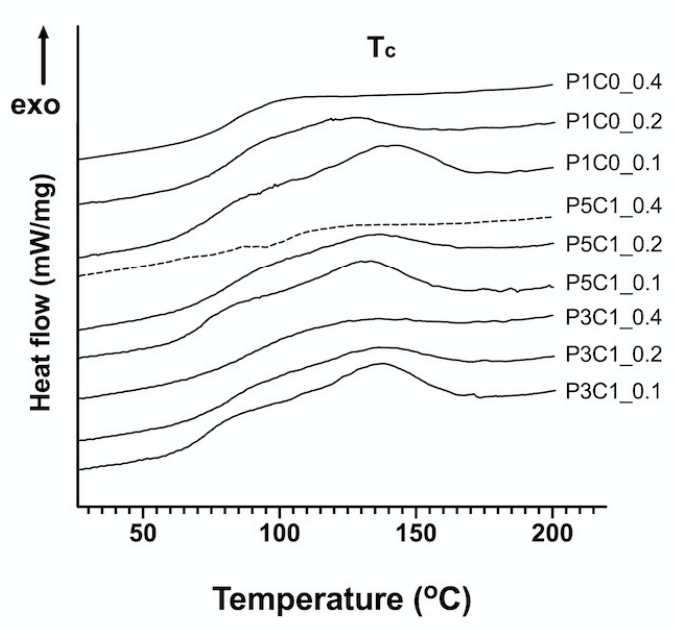

Figure 3. Differential scanning calorimetry (DSC) thermal analysis of scaffolds (exo up). P1C0 control, P5C1, and P3C1 scaffolds with different GA/PVA crosslinking ratios of 0.4, 0.2, and 0.1. (A) Heating curves and (B) cooling curves; dashed lines in the heating curves indicate three groups without $\mathrm{T}_{\mathrm{m}}$ peaks (GA/PVA crosslinking ratio of 0.4 ). The dashed line in cooling curve indicates the group without $\mathrm{T}_{\mathrm{c}}$ peak (P5C1_0.4). P1C0 is PVA/CMC = 1:0; P5C1 is PVA $/ \mathrm{CMC}=5: 1$; $\mathrm{P} 3 \mathrm{C} 1$ is $\mathrm{PVA} / \mathrm{CMC}=3: 1$.

The melting temperature $\left(\mathrm{T}_{\mathrm{m}}\right)$ was located at another decrease of the heat flow around $150{ }^{\circ} \mathrm{C}$ (Figure $\left.3 \mathrm{~A}\right)$. When the crosslinking ratio decreased from 0.2 to $0.1, \mathrm{~T}_{\mathrm{m}}$ increased to $156.5^{\circ} \mathrm{C}$ for $\mathrm{P} 1 \mathrm{C} 0,154.6^{\circ} \mathrm{C}$ for $\mathrm{P} 5 \mathrm{C} 1$ and $157.7^{\circ} \mathrm{C}$ for P3C1 (Figure S1). At a crosslink ratio of 0.4 , the $\mathrm{T}_{\mathrm{m}}$ values of all groups were unable to be determined, as indicated by dashed lines in Figure 3A. When the crosslinking ratio decreased to 0.1, the crystallization temperature $\left(\mathrm{T}_{\mathrm{c}}\right)$ of the P1C0 control group increased, as demonstrated by the highest $\mathrm{T}_{\mathrm{C}}$ of $142.4^{\circ} \mathrm{C}$ (Figure $3 \mathrm{~B}$ and Figure $\mathrm{S} 1$ ). The addition of CMC tended to increase $\mathrm{T}_{\mathrm{C}}$ of P5C1 and P3C1 groups, but varying crosslinking ratios did not affect $\mathrm{T}_{\mathrm{C}}$ of these two groups. Specifically, in the $\mathrm{P} 3 \mathrm{C} 1$ group, crosslinking ratios of 0.2 and 0.4 showed similar $\mathrm{T}_{\mathrm{C}}$ (135.9 ${ }^{\circ} \mathrm{C}$ for crosslinking ratio 0.2 vs. $136.6{ }^{\circ} \mathrm{C}$ for 0.4 ). Surprisingly, $\mathrm{T}_{\mathrm{C}}$ of P5C1 group at a crosslinking ratio of 0.4 was not detected as indicated by dashed line in Figure $3 \mathrm{~B}$.

\subsection{Micromorphological Assessment}

The porosity of PVA/CMC scaffolds was visualized by scanning electron microscopy (SEM). P1C0 control scaffolds at a GA/PVA crosslinking ratio of 0.4 displayed thick walls and small pore sizes (Figure 4). When the crosslinking ratio decreased to 0.2 and 0.1 , thinner walls were observed. A porous structure of the P1C0 control group was not observed for the lowest crosslinking ratio, 0.05 .

Interestingly, incorporation of CMC resulted in larger pore sizes in P5C1 and P3C1 groups. The P3C 1 groups at a crosslinking ratio of 0.4 exhibited pore sizes of $50-80 \mu \mathrm{m}$, which were larger than those observed in the P5C1 group and P1C0 control group. The pore sizes of the $\mathrm{P} 5 \mathrm{C} 1$ group decreased when the crosslinking ratio was reduced to 0.2 and 
0.1. In contrast, the $\mathrm{P} 3 \mathrm{C} 1$ group exhibited larger pore sizes $(50 \mu \mathrm{m})$ and thin walls at a crosslinking ratio of 0.1 (Figure 4).

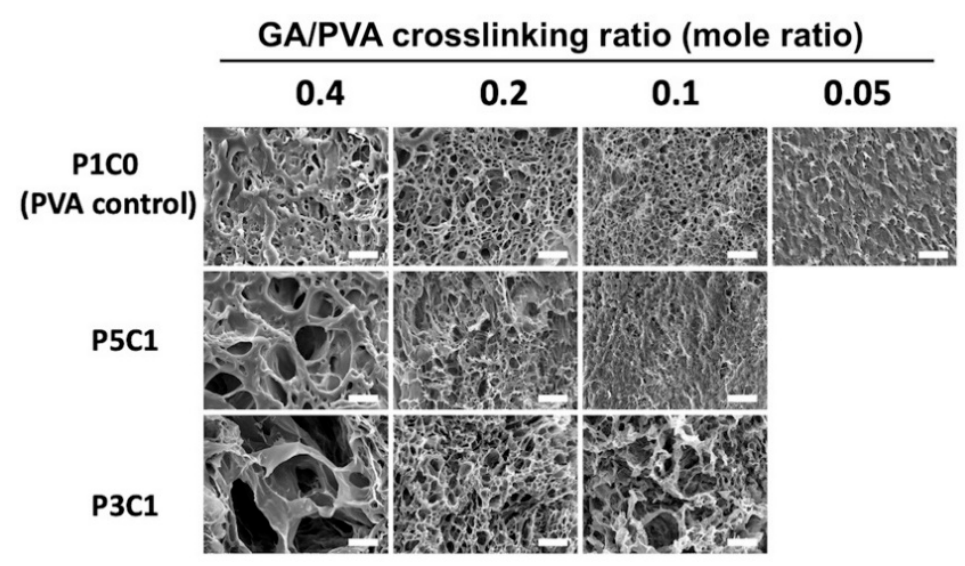

Figure 4. SEM images of PVA/CMC scaffolds. Hydrogels were crosslinked by GA at different mole ratios of GA/PVA and freeze-dried. PVA without CMC (P1C0) served as a control group. Scale bar $=50 \mu \mathrm{m} . \mathrm{P} 1 \mathrm{C} 0$ is PVA $/ \mathrm{CMC}=1: \mathrm{P}$ P5C1 is PVA $/ \mathrm{CMC}=5: 1 ; \mathrm{P} 3 \mathrm{C} 1$ is PVA $/ \mathrm{CMC}=3: 1$.

\subsection{Mechanical Analysis of Scaffolds}

The compressive modulus of the scaffolds was evaluated (Figure 5). The highest Young's modulus ( $344.74 \pm 52 \mathrm{kPa}$ ) was observed in the P1C0 control group at a GA/PVA crosslinking ratio of 0.4 (Figure 5 and Figure S2). CMC incorporation resulted in P5C1 and P3C1 groups having a significantly lower Young's modulus compared to the control group. At a crosslinking ratio of 0.1 , when CMC content increased, Young's modulus decreased from $175.40 \pm 24.3 \mathrm{kPa}$ in the control group to $23.73 \pm 5.93$ and $14.77 \pm 1.49 \mathrm{kPa}$ in the P5C1 and P3C1 groups, respectively. The decrease in Young's modulus was also observed for the crosslinking ratio of 0.2 .

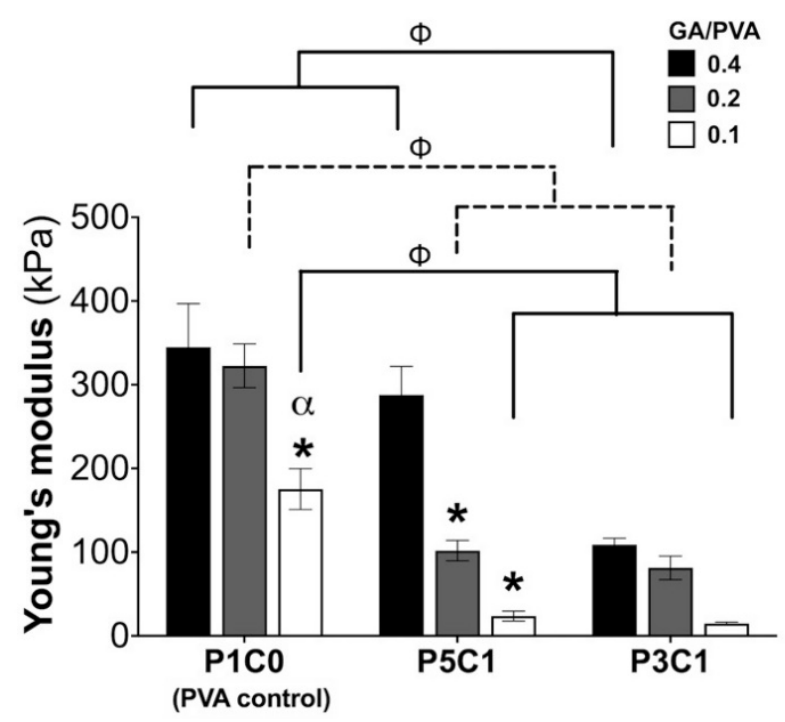

Figure 5. Young's modulus of PVA/CMC scaffolds. The Young's modulus of scaffolds of different CMC contents ( $\mathrm{P} 1 \mathrm{C} 0$ is PVA/CMC $=1: 0 ; \mathrm{P} 5 \mathrm{C} 1$ is PVA $/ \mathrm{CMC}=5: 1 ; \mathrm{P} 3 \mathrm{C} 1$ is $\mathrm{PVA} / \mathrm{CMC}=3: 1$ ) and three crosslinking ratios (GA/PVA crosslink $=0.4,0.2$, and 0.1 ) was determined. Data show average \pm standard error; $n=4 .{ }^{\phi}$ indicates significant effects of CMC. ${ }^{*}$ and ${ }^{\alpha}$ indicate significant effects of crosslinking ratios within the same group, where ${ }^{*}$ and ${ }^{\alpha}$ are compared with crosslinking ratios of 0.4 and 0.2 , respectively.

Interestingly, the $\mathrm{P} 5 \mathrm{C} 1$ group at a crosslinking ratio of 0.2 and $\mathrm{P} 3 \mathrm{C} 1$ group at a crosslinking ratio of 0.4 displayed a similar Young's modulus $(\sim 100 \mathrm{kPa})$. Based on the 
similarity in Young's modulus for these two groups, they were chosen for cell seeding and cell viability testing.

\subsection{Swelling Behaviors of PVA/CMC Scaffolds}

The swelling ratio and swelling rate of PVA/CMC scaffolds were evaluated in PBS. P1C0 control scaffolds did not show significant differences in swelling ratio when GA/PVA crosslinking ratios were decreased from 0.4 to 0.05 (Figure 6A). Effects of incorporation of CMC on water absorption into scaffolds was demonstrated by a significant change in swelling ratio in the $\mathrm{P} 5 \mathrm{C} 1$ and $\mathrm{P} 3 \mathrm{C} 1$ groups, especially at the GA/PVA crosslinking ratio of 0.1 (Figure $6 \mathrm{~B}, \mathrm{C}$ ). At the lowest crosslinking ratio, 0.05 , only the P1C0 control group could form hydrogel (Figure 1), and swelling behaviors of the scaffolds could be observed (Figure 6A, $\nabla$ ).
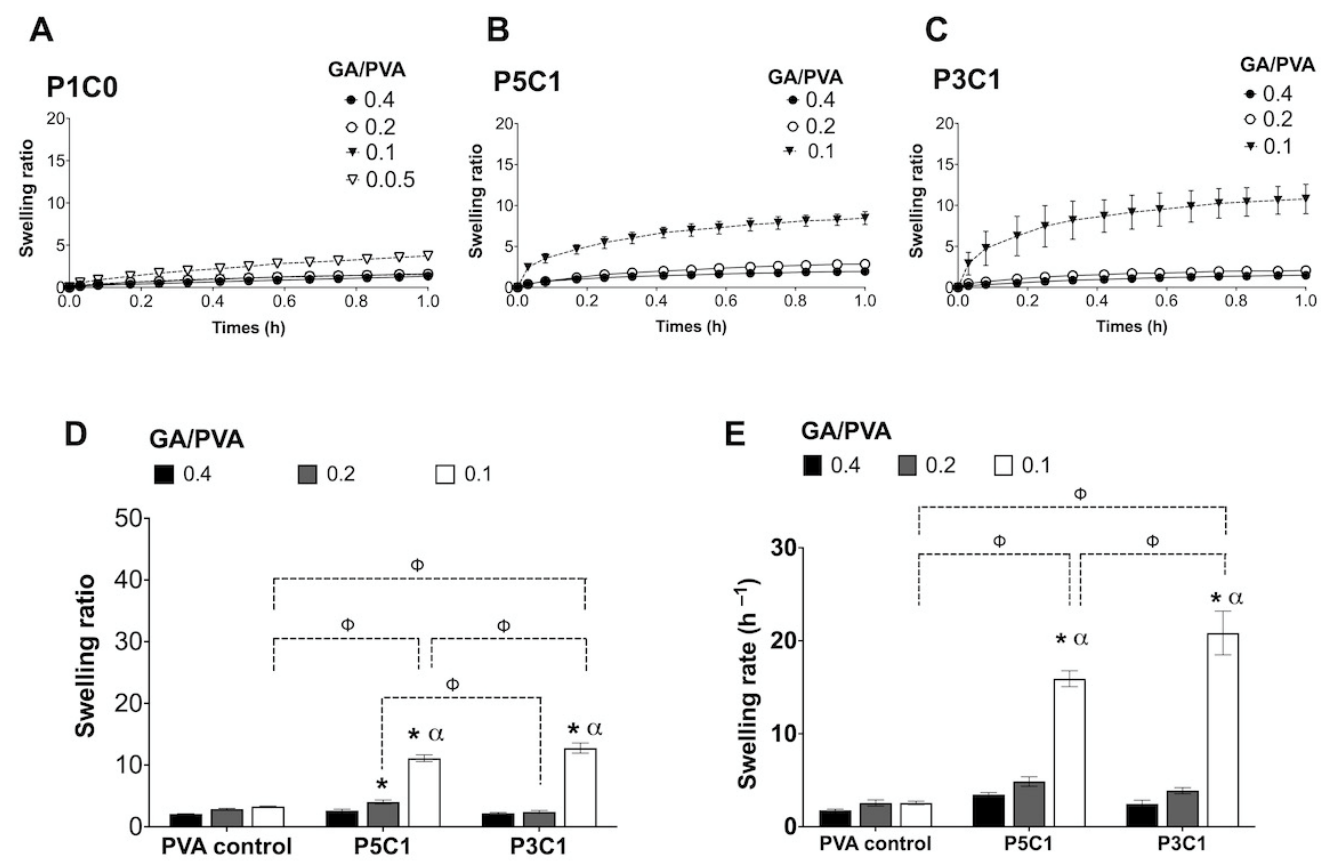

Figure 6. Swelling ratio. Swelling ratios of P1C0 (A), P5C1 (B) and P3C1 (C) were recorded for $1 \mathrm{~h}$. The maximum swelling ratio at $24 \mathrm{~h}(\mathbf{D})$. Swelling rate of scaffolds was determined linearly over $30 \mathrm{~min}$ intervals (E). Data show average \pm standard error; $\mathrm{n}=4$. ${ }^{\phi}$ indicates significant effects of $\mathrm{CMC}$. ${ }^{*}$ and ${ }^{\alpha}$ indicate significant effects of crosslinking compared with GA/PVA crosslinking ratios of 0.4 and 0.2 , respectively.

After $24 \mathrm{~h}$ (Figure 6D), the highest swelling ratio was observed in $\mathrm{P} 3 \mathrm{C} 1$ at the crosslinking ratio of $0.1(12.76 \pm 0.82)$. An increase in GA/PVA crosslinking ratio to 0.4 decreased water absorption in both CMC incorporated groups, P5C1 and P3C1. However, swelling behaviors of control PVA did not change regardless of crosslinking ratio (Figure 6D). In the P5C1 and P3C1 groups, the GA/PVA crosslinking ratio of 0.1 showed a significant increase in swelling behaviors compared to GA/PVA crosslinking ratios of 0.2 and 0.4 . The highest swelling rate was observed in the $\mathrm{P} 3 \mathrm{C} 1$ group at a crosslinking ratio of 0.1 $\left(20.84 \pm 2.35 \mathrm{~h}^{-1}\right)$ followed by the swelling rate of the $\mathrm{P} 5 \mathrm{C} 1$ group at a crosslinking ratio of $0.1\left(15.91 \pm 0.86 \mathrm{~h}^{-1}\right)$ (Figure $\left.6 \mathrm{E}\right)$. The swelling rate corresponded with the swelling ratio in the $\mathrm{P} 3 \mathrm{C} 1$ group, which contained a higher water content and absorbed water into scaffolds faster than other groups. In addition, PVA/CMC scaffolds were submerged in PBS to investigate the in vitro degradation for 8 weeks, with results reported as percentage of remaining weight. Significant mass loss could not be detected in all groups (Figure S3).

\subsection{Assessment of Cell Distribution and Cytotoxicity of PVA/CMC Scaffolds}

A LIVE/DEAD cell viability assay was performed on day 7 post-seeding. Chondrocytes showed a homogeneous distribution in $\mathrm{P} 5 \mathrm{C} 1$ scaffolds at a crosslinking ratio of 0.2 
and $\mathrm{P} 3 \mathrm{C} 1$ scaffolds at a crosslinking ratio of 0.4 . Green live cells and red auto-fluorescence of scaffolds could be observed in both groups (Figure 7A).
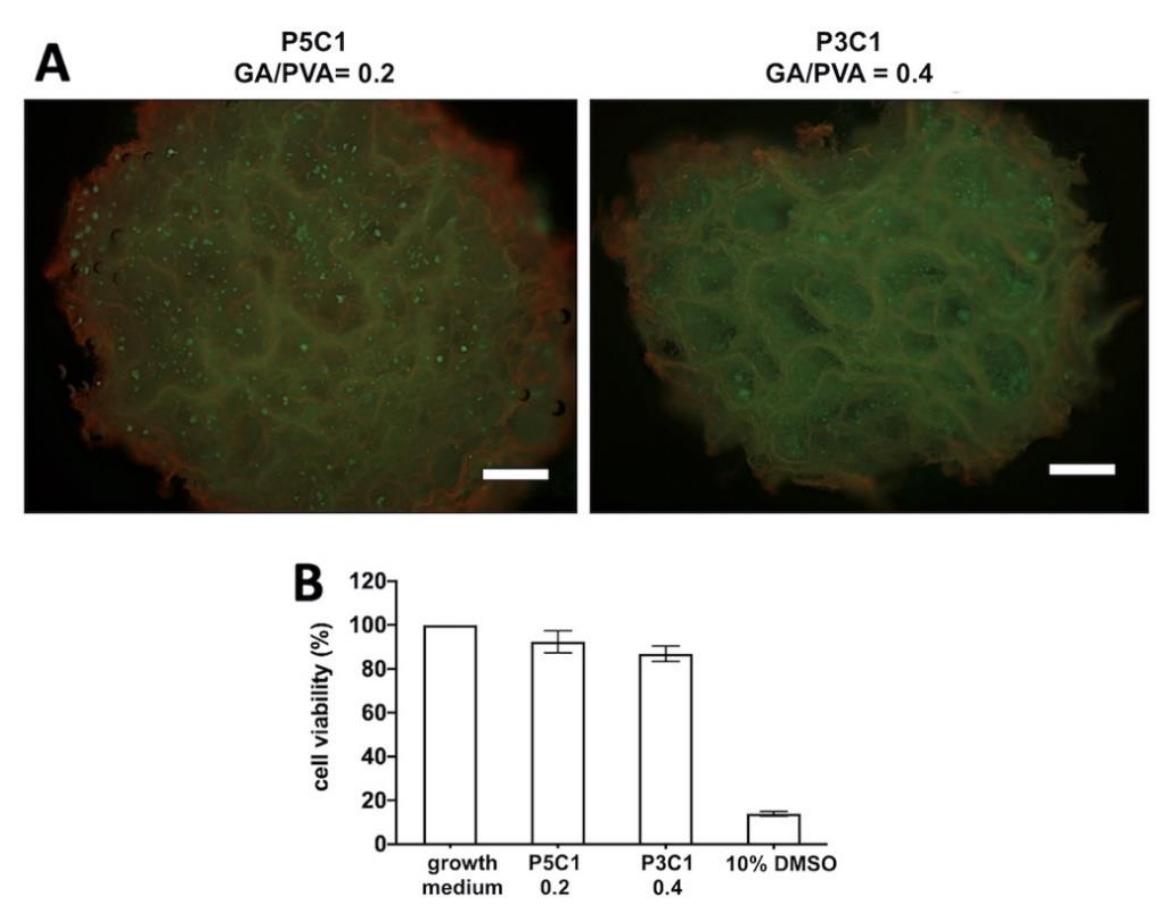

Figure 7. Assessment of cell distribution and cell viability. Chondrocytes were homogenously distributed in the P5C1 scaffold at a crosslinking ratio of 0.2 and in the $\mathrm{P} 3 \mathrm{C} 1$ scaffold at a crosslinking ratio of 0.4 ; scale bar $=50 \mu \mathrm{m}(\mathrm{A})$. Cell viability of chondrocytes cultured in PVA/CMC scaffold extracts (B).

Viability percentages of chondrocytes cultured in PVA/CMC scaffold extracts were higher than $70 \%$. The viability percentage of $\mathrm{P} 5 \mathrm{C} 1$ at a crosslinking ratio of 0.2 was $92.32 \%$, and that of $\mathrm{P} 3 \mathrm{C} 1$ at a crosslinking ratio of 0.4 was $86.91 \%$ (Figure 7B), indicating non-toxicity of PVA/CMC scaffolds against chondrocytes. Growth medium and 10\% DMSO served as negative and positive controls for cytotoxicity, respectively.

\section{Discussion}

Cell-based cartilage tissue repair in conjunction with biopolymers provides treatment options by creating functional tissues to replace diseased and damaged ones. Our study developed porous scaffolds for potential use in cartilage tissue engineering by entrapping plant-based carboxymethylcellulose (CMC) in a polyvinyl alcohol (PVA) network resulting in PVA/CMC scaffolds. We hypothesized that incorporation of CMC increases hydrated environment in scaffolds to promote cell adhesion without cytotoxicity. CMC is a carbohydrate-derived polymer with excellent water absorption and biodegradable properties, while PVA is an FDA-approved synthetic polymer. We demonstrated how to control mechanical properties, swelling behaviors, and potential use of scaffolds as cell carrier for cartilage tissue development via incorporation of CMC into PVA and varying degrees of glutaraldehyde crosslinking.

The advantages of using glutaraldehyde crosslinking are that thermal treatment and catalysts are not required in this study, making scaffold production easily to handle. However, the absence of a catalyst or thermal treatment during the crosslinking reaction resulted in slow hydrogel formation or failure to form hydrogel [19]. In this study, PVA/CMC solution took $10-14$ days at $25^{\circ} \mathrm{C}$ to become hydrogel. Adding hydrochloric acid $(\mathrm{HCl})$ as a catalyst allows faster crosslinking time, and this can be achieved by directly mixing PVA solution with $\mathrm{HCl}[20,21]$ and exposing PVA nanofibers and film to glutaraldehydehydrochloric acid vapor [22,23]. The crosslinking used in this study was based on mole 
ratio, which takes functional groups of GA and PVA into account. Swelling ratio decreased for all scaffolds at high GA/PVA crosslinking ratios, similarly to results reported for PVA films and hydrogels [20,24,25]. At a high GA/PVA crosslink ratio, glutaraldehyde used up hydroxyl groups on PVA molecules. A decrease in hydroxyl groups led to an increase in hydrophobicity of scaffolds, which resulted in less water absorption, as demonstrated by the very low swelling behaviors of all scaffolds at GA/PVA crosslinking ratio of 0.4 . Besides GA, other crosslinking agents, such as epichlorohydrin [26] and citric acid [27], were used to crosslink PVA and CMC mixture under alkaline or acidic conditions at high temperature. These crosslinking reactions resulted in different products: crosslinked PVA-PVA, PVA-CMC, and CMC-CMC.

Swelling behaviors of PVA/CMC scaffolds could be explained by two counteracting forces, which are swelling pressures from CMC and tensile strengths from PVA networks. PVA networks were formed via acetal bridges that linked hydroxyl groups on PVA with aldehyde groups on glutaraldehyde, while CMC was trapped inside the networks absorbing water. ATR-FTIR analysis of PVA/CMC scaffolds showed a decrease in transmittance intensity of the stretching $\mathrm{O}-\mathrm{H}$ (at $3321-3360 \mathrm{~cm}^{-1}$ ) after glutaraldehyde crosslinking. A decrease in the intensity might occur as a result of the formation of acetal bridges, while the stretching $\mathrm{O}-\mathrm{H}$ bands in control PVA powder was maintained at a high intensity. The clear signal at $1599 \mathrm{~cm}^{-1}$ of P3C1 and P5C1 confirmed incorporation of CMC in the PVA hydrogel network.

P3C1 scaffolds with high CMC content showed a significantly higher swelling ratio compared with $\mathrm{P} 5 \mathrm{C} 1$ and control groups, indicating a highly hydrophilic nature of CMC. Interestingly, $\mathrm{P} 5 \mathrm{C} 1$ and $\mathrm{P} 3 \mathrm{C} 1$ groups contained the same amount of PVA as the P1C0 control group $(12.5 \%(w / v))$, but they were dissolved and could not form hydrogel at a GA/PVA crosslinking ratio of 0.05 . It is possible that P5C1 and P3C1 groups did not contain sufficient crosslinking networks, covalent bonds generated from carbonyl groups (-CHO) of glutaraldehyde and hydroxyl groups $(-\mathrm{OH})$ of PVA. Specifically, acetal bridges in $\mathrm{P} 5 \mathrm{C} 1$ and $\mathrm{P} 3 \mathrm{C} 1$ hydrogels could not withstand an increase in swelling pressure generated from negatively charged (carboxyl groups, $\mathrm{COO}^{-}$) of $\mathrm{CMC}$, resulting in hydrogel falling apart. An increase in GA/PVA crosslinking ratio up to 0.1 was sufficient to counteract swelling pressure in P5C1 and P3C1 groups.

This study demonstrated the use of freeze-drying to create the pore structure of threedimensional scaffolds. As seen in SEM images (Figure 4), incorporating CMC into PVA hydrogel increased the pore size of scaffolds. When hydrogel was soaked in water before the freeze-drying step, both P5C1 and P3C1 hydrogels absorbed water more than the PVA control group, resulting in more ice crystals inside scaffolds. After sublimating, larger pore cavities were left behind in P5C1 and P3C1 scaffolds compared to PVA control scaffolds.

In addition, larger pore sizes were clearly observed at the high GA/PVA crosslinking ratio of 0.4 , while at a low crosslinking ratio porous structure was not clearly present in scaffolds. One plausible explanation for this observation is related to low crosslink density of the hydrogel network, resulting in collapse of pore walls. However, it is interesting to note that pore size of the P3C1 group increased at the low crosslinking ratio of 0.1 . With freeze-drying, PVA/CMC scaffolds exhibited 12- to 15-fold lower swelling ratios after reach equilibrium compared to the scaffolds that did not proceed to the freeze-drying process, without the pore formation step (Figure S4). The low swelling ratio observed in freeze-dried scaffolds in this study was affected by the drying process, which possibly interfered with hydrophilic groups on polymers to attract water. Nevertheless, newly formed large pores and good connectivity led to an ideal scaffold for cell seeding generated from freeze-drying, which contributed to scaffold swelling through water-filled pores. The porous structure in a scaffold is important for cartilage tissue engineering to quickly absorb joint liquid and to allow cell migration and ingrowth into scaffolds [8]. In our study, the $\mathrm{P} 5 \mathrm{C} 1$ scaffold at a crosslinking ratio of 0.2 and $\mathrm{P} 3 \mathrm{C} 1$ scaffold at a crosslinking ratio of 0.4 exhibiting large pore sizes of around $50-100 \mu \mathrm{m}$ were chosen to study cell viability. 
Reduction of the crosslinking ratio from 0.4 to 0.2 did not affect mechanical properties of $\mathrm{P} 1 \mathrm{C} 0$ control groups. It is possible that the acetal bridge easily formed in $\mathrm{P} 1 \mathrm{C} 0$ hydrogel because $\mathrm{CMC}$ was not present in the hydrogel mixture to hinder the crosslinking process. Therefore, a crosslink ratio of 0.2 for the P1C0 group was sufficient to increase mechanical properties of the scaffolds. Interestingly, incorporation of CMC into PVA at a mass ratio PVA/CMC $=5: 1$ significantly modulated mechanical properties of porous scaffolds as seen in the increment of Young's modulus when crosslinking ratio was increased (Figure 5). While CMC content increased to one-third of PVA mass, mechanical properties of P3C1 scaffolds did not change regardless of increasing GA/PVA ratio (Figure 5). It is possible that glutaraldehyde inefficiently reacted with hydroxyl groups on PVA due to high CMC contents in P3C1 hydrogel mixture preventing acetal bridge formation. This study suggested that modulation of mechanical properties by glutaraldehyde crosslink occurred when CMC content at one-fifth of PVA mass was incorporated into the hydrogel mixture.

Ideally, scaffold for cartilage repair should mechanically resist load in in vivo joints and provide a three-dimensional structure for cell growth and nutrient transport and hydrated environment similar to native tissue with water content in a range of $70 \%$ to $80 \%[28,29]$. In our study, two formulas of PVA/CMC scaffolds were chosen to study chondrocyte viability. The first formula was for P5C1 scaffolds at a GA/PVA crosslinking ratio of 0.2 , and the second was for $\mathrm{P} 3 \mathrm{C} 1$ scaffolds at a GA/PVA crosslinking ratio of 0.4 . These two scaffolds exhibited similar water content to native cartilage of approximately $70 \%$ (Figure S5) and similar mechanical properties.

Previously, we seeded chondrocytes on P1C0 control scaffolds and found that cells could not adhere to the scaffold and sedimented at the bottom of the cell culture tubes. One plausible explanation for poor cell attachment of the control scaffolds is their hydrophobic surface that results from a decrease of hydroxyl groups during glutaraldehyde crosslinking. Kim et.al. demonstrated that biomolecules in serum containing media could modulate cell binding affinity and shape [30]. In the current study, cell-scaffold interaction was minimally influenced by serum protein absorption because serum-free growth medium was used during 7-day post-cell seeding. The variety of substrates was investigated the effects of charges on cell adhesion. It has been generally accepted that positively charged substrates bind negatively charged cell membranes via electrostatic interaction [31]. In addition, Webb et al. demonstrated greater cell attachment on hydrophilic and positively charged amine-modified surfaces compared to hydrophobic surfaces [32]. We have limited information on characterization of PVA/CMC scaffolds in terms of the mechanism behind cell adhesion. At physiological pH 7.4, PVA/CMC scaffolds are expected to contain negatively charged carbonyl groups (- $\left.\mathrm{CH}_{2} \mathrm{COO}-\right)$ from $\mathrm{CMC}$ and non-charged hydroxyl groups $(-\mathrm{OH})$ on PVA, which contribute to hydrophilicity of the scaffold. Further study will be necessary to elucidate the underlining mechanism of cell adhesion to the PVA/CMC scaffold, which is one of criteria of biocompatibility besides normal cell function, migration to scaffolds, and proliferation before laying down a new matrix [33].

PVA was not chemically covalent with CMC, but these two polymers co-existed via interpenetrating network (IPN) to form hydrogel without any covalent bonds between them [34]. Our study demonstrated that hydroxyl groups on PVA formed covalent bonds with glutaraldehyde, while CMC entangled the polymer network. No differences were found in solid-state NMR spectra between P3C1 and P1C0 control groups (Figure S6). New functional groups were also not present in the NMR spectra of the $\mathrm{P} 3 \mathrm{C} 1$ group. Unlike IPN hydrogel, single network hydrogels have a slow response to water absorption [35]. We demonstrated that the P1C0 control group exhibited an 8-times slower swelling rate compared to the $\mathrm{P} 3 \mathrm{C} 1$ group at a crosslinking ratio of 0.1 . Fast swelling response promotes cell seeding efficiency, due to quick cell absorption into scaffolds. It has been previously reported that IPN was used to construct cartilage scaffolds using alginate and chitosan (natural polymers) [36] as well as gelatin and polycaprolactone-polyethylene glycol (natural and synthetic polymers) [37]. The PVA/CMC scaffolds in this study displayed structural 
advantages through mechanical stability of the PVA network and high crosslinking density, and at the same time they maintained a hydrated environment through incorporating CMC.

PVA control scaffolds might have a rigid amorphous structure, which requires higher temperature to heat up its polymer chains from brittle-solid to viscous rubbery state [38,39]. $\mathrm{CMC}$ incorporation and low crosslinking ratio tended to decrease $\mathrm{T}_{\mathrm{g}}$ of the PVA/CMC scaffolds, as demonstrated by low $\mathrm{T}_{\mathrm{g}}$ in the $\mathrm{P} 5 \mathrm{C} 1$ and $\mathrm{P} 3 \mathrm{C} 1$ groups. It is possible that CMC caused PVA polymer chains to move around easily. Previous studies reported polymer blend decreased $\mathrm{T}_{\mathrm{g}}$ [40]. In those studies, an increase in chitosan contents in PVA solution slightly decreased $\mathrm{T}_{\mathrm{g}}$ of the thin film blend. High density of crosslinking, the acetal bridge network in this case, reduced the freedom of motion of the segments of the polymer chains and thus increased $\mathrm{T}_{\mathrm{g}}$ [38]. We demonstrated that incorporation of CMC possibly impeded acetal bridge formation. In addition, our study showed that $\mathrm{T}_{\mathrm{g}}$ could be restored by increasing GA/PVA crosslinking ratio.

At a GA/PVA crosslinking ratio of 0.4 , all groups did not show $\mathrm{T}_{\mathrm{m}}$ in DSC curves (Figure $3 \mathrm{~A}$ ). The absence of $\mathrm{T}_{\mathrm{m}}$ peaks in all the three groups at high crosslinking ratio might be from their amorphous structure, which prevented the detection of melting points [41]. Interestingly, only P5C1 scaffolds at a GA/PVA crosslinking ratio of 0.4 did not show both $\mathrm{T}_{\mathrm{m}}$ and $\mathrm{T}_{\mathrm{c}}$. However, we cannot explain why scaffolds at low crosslinking ratios of 0.2 and 0.1 exhibited higher $\mathrm{T}_{\mathrm{m}}$ than scaffolds at the high crosslinking ratio of 0.4 (Figure S1). Generally, polymer chains are less restricted at low crosslinking density, which allows them easily to slide across one another. In addition, we found that addition of CMC tended to increase $\mathrm{T}_{\mathrm{m}}$ of the porous scaffolds. The higher melting temperature of the scaffold was possibly influenced by $\mathrm{CMC}\left(274^{\circ} \mathrm{C}\right)$, which has a higher melting point than PVA $\left(\sim 200^{\circ} \mathrm{C}\right)$.

Crystallization is an exothermic process that occurs when polymers move from a disorder state after melting to a more ordered crystalline state and release the amount of energy difference between those two states while cooling down [39]. Crosslinking restricts chain motion that could prevent crystallization after cooling down. In the P1C0 control group, GA/PVA crosslinking ratio increased from 0.1 to 0.4 , resulting in a decrease of $\mathrm{T}_{\mathrm{c}}$. A similar observation of low $\mathrm{T}_{\mathrm{c}}$ and $\mathrm{T}_{\mathrm{m}}$ after an increase in crosslinking ratio was reported in poly(L-lactide) (PLLA) electrospun nanomat [42] and poly(butylene succinate) hydrogel [43]. Our study showed that $\mathrm{T}_{\mathrm{c}}$ of PVA/CMC scaffolds was independent from crosslinking density, as demonstrated in similar $\mathrm{T}_{\mathrm{C}}$ of $\mathrm{P} 5 \mathrm{C} 1$ and $\mathrm{P} 3 \mathrm{C} 1$ groups ranging from 133 to $136^{\circ} \mathrm{C}$ regardless of crosslinking ratio.

Functional cartilage tissue requires incorporation of living cells into scaffolds, which serve as structural support for cell adhesion and new matrix deposition. The PVA/CMC scaffolds derived from synthetic and natural polymers in this study not only provided porous structure for chondrocyte seeding but also acknowledged green chemistry movement. Compared to other fields, tissue engineering does not represent green and ecofriendly technologies because traditional scaffold fabrication processes still employ toxic solvents [44]. The use of plant-derived polysaccharides blended with PVA has emerged in biomedical applications, such as wound healing hydrogel [45], drug release hydrogel film [26,27], and cryogel scaffolds for bone tissue engineering [46]. Biocompatibility, biodegradability, and plant proteins abundant in nature (soy, zein, gluten) attract much attention as alternative scaffolding biomaterials for regenerative medicine. Green chemistryinspired scaffolds in our study reduced the use of toxic and harmful materials and method. Cellulose-derived biomaterials were incorporated to create hydrated microenvironment of scaffolds without acidic conditions in the crosslinking process. Although glutaraldehyde was used as a crosslinking agent, its toxicity was inactivated by glycine during the preparation of scaffolds.

In conclusion, porous scaffolds were developed from CMC entrapped in a PVA network. The data presented in this work suggest that the scaffolds can be tailored in terms of pore sizes, mechanical properties, and water contents by modulating crosslinking 
density and CMC contents. We demonstrated that PVA/CMC scaffolds possessed biological cues from plant-derived polymers and structural supports from synthetic polymers. The scaffolds showed biocompatibility with chondrocytes and may have great potential for applications in cartilage regeneration.

\section{Materials and Methods}

\subsection{Chemicals and Reagents}

Polymers used for scaffold fabrication were polyvinyl alcohol $\left(\mathrm{M}_{\mathrm{W}}=85,000-124,000 \mathrm{~g} / \mathrm{mol}\right)$ and sodium carboxymethyl cellulose (MW $=\sim 90,000 \mathrm{~g} / \mathrm{mol}$, degree of substitution 0.7). These polymers were purchased from Sigma-Aldrich (St. Louis, MO, USA). Glutaraldehyde (03965) was purchased from Loba Chemie (Mumbai, India). High glucose DMEM (D777) used in tissue culture was purchased from Sigma-Aldrich (St. Louis, MO, USA). Gibco ${ }^{\mathrm{TM}}$ HEPES (Waltham, MA, USA) (15630-080) and Gibco ${ }^{\mathrm{TM}}$ antibiotic-antimycotic (Waltham, MA, USA) (A5955) were purchased from ThermoFisher Scientific (Waltham, MA, USA). Serum replacement solution (SR-100) was purchased from PeproTech (Rocky Hill, NJ, USA). TrypLE ${ }^{\mathrm{TM}}$ Express Enzyme (Waltham, MA, USA) (12604021) and Invitrogen ${ }^{\mathrm{TM}}$ LIVE/DEAD ${ }^{\circledR}$ viability/cytotoxicity kit (Waltham, MA, USA) (L3224) were purchased from ThermoFisher Scientific (MA, USA).

\subsection{Preparation of Porous PVA/CMC Scaffolds}

Polyvinyl alcohol (PVA) was mixed with carboxymethyl cellulose (CMC) at different mass ratios (Table 1). CMC (1.25 g or $2.09 \mathrm{~g}$ ) was dissolved in deionized (DI) water, mixed well, and heated at $80{ }^{\circ} \mathrm{C}$ overnight. PVA (6.25 g) was slowly added into CMC thick solution and heated at $80{ }^{\circ} \mathrm{C}$ overnight to increase homogeneity. The polymer mixture was centrifuged at $1500 \mathrm{rpm}$ for $2 \mathrm{~min}$. Glutaraldehyde (GA) was added to the polymer mixture (Figure S8). PVA polymer solutions without CMC served as control groups. Summaries of the PVA/CMC mass ratios and GA/PVA mole ratios are shown in Table 1.

Table 1. Preparation of PVA/CMC scaffolds with different glutaraldehyde crosslinking. PVA and CMC were mixed and crosslinked by GA. P1C0 (PVA/CMC =1:0) served as control group by the addition of water instead of CMC.

\begin{tabular}{cccccc}
\hline \multirow{2}{*}{ Scaffolds } & $\begin{array}{c}\text { PVA/CMC } \\
\text { Mass Ratio }\end{array}$ & \multicolumn{4}{c}{ Crosslink Ratio (GA/PVA Mole Ratio) } \\
\cline { 3 - 6 } & P1C0 & $\mathbf{0 . 4}$ & $\mathbf{0 . 2}$ & $\mathbf{0 . 1}$ & $\mathbf{0 . 0 5}$ \\
\hline (control) & $1: 0$ & $\mathrm{O}$ & $\mathrm{O}$ & $\mathrm{O}$ & $\mathrm{O}$ \\
\hline P5C1 & $5: 1$ & $\mathrm{O}$ & $\mathrm{O}$ & $\mathrm{O}$ & $\mathrm{X}$ \\
\hline P3C1 & $3: 1$ & $\mathrm{O}$ & $\mathrm{O}$ & $\mathrm{O}$ & $\mathrm{X}$ \\
\hline PVA = polyvinyl alcohol, CMC $=$ carboxymethylcellulose, GA = glutaraldehyde, $\mathrm{O}=$ gel, $\mathrm{X}=$ not gel.
\end{tabular}

$\overline{\mathrm{PVA}}=$ polyvinyl alcohol, $\mathrm{CMC}=$ carboxymethylcellulose, $\mathrm{GA}=$ glutaraldehyde, $\mathrm{O}=$ gel, $\mathrm{X}=$ not gel.

Five milliliters of homogeneous mixture were poured into 6-well plates. The plates were sealed with Parafilm and left in a chemical hood for 14 days. Hydrogels were soaked in $5 \mathrm{~L}$ of DI water for $48 \mathrm{~h}$. The hydrogels in 6-well plates were transferred to $-20^{\circ} \mathrm{C}$ and kept overnight. Cylinder constructs were taken from the frozen hydrogel using a biopsy punch $8 \mathrm{~mm}$ in diameter, cut to a desired height of $5 \mathrm{~mm}$, and washed with DI water for 2 days with 3 changes of DI water per day. To inactivate uncrosslinked glutaraldehyde, hydrogel constructs were incubated in glycine $(50 \mathrm{mM})$ on a rocker overnight and washed with distilled water for $24 \mathrm{~h}$. The constructs were frozen at $-80^{\circ} \mathrm{C}$ for $18 \mathrm{~h}$ with a cooling rate of $1{ }^{\circ} \mathrm{C} /$ minute and transferred into a freeze-dryer (Alpha-4, Martin Christ, Germany) for $24 \mathrm{~h}$. Dried scaffolds were soaked in absolute ethanol, air-dried, and exposed to UV light for $15 \mathrm{~min}$. The samples were stored in sterile bottle until use in cell seeding experiment.

\subsection{Characterization of Porous Scaffold}

For FTIR measurement, scaffolds were cut into $2 \times 2 \mathrm{~mm}^{2}$ samples and analysed in ATR mode. FTIR spectra were obtained in the range of wavenumber from 4000 to 
$400 \mathrm{~cm}^{-1}$. The spectrum was averaged over 64 scans with $4.0 \mathrm{~cm}^{-1}$ resolutions (Perkin Elmer, Spectrum One, USA). For DSC characterization, scaffolds (5-10 mg) were heated from 25 to $220^{\circ} \mathrm{C}$ under $\mathrm{N}_{2}$ at a linear heating rate of $10 \mathrm{~K} / \mathrm{min}$ (DSC $204 \mathrm{~F} 1$ Phoenix ${ }^{\circledR}$, Selb, Germany). For solid state NMR analysis, the $1 \mathrm{D}^{13} \mathrm{C}$ Cross-Polarization Magic Angle Spinning (CP/MAS) spectra of scaffolds were acquired using a $400 \mathrm{MHz}$ solid-state Nuclear Magnetic Resonance spectrometer AVANCE III, Bruker (Billerica, MA, USA) at $100 \mathrm{MHz}$, with $4 \mathrm{~mm}$ PH MAS 400WB BL4 N-P/H DVT probe. The 2341 scans were induced and collected over a spectral width of $30 \mathrm{kHz}$, with a recycle delay of $3 \mathrm{~s}$. Glycine at $176.04 \mathrm{ppm}$ was used as standard sample for chemical shift. The spectra were analysed by MNova 14.1.0 (Mestrelab Research).

\subsection{Micromorphological Assessment}

After freeze drying, scaffolds were removed water content by sequential ethanol series $(10 \%, 30 \%, 50 \%, 70 \%, 80 \%, 90 \%, 95 \%$, and 100\% ethanol) and evaporated using an automated critical point dryer (Leica EM CPD300). Dried scaffold was fractured into small pieces and sputter-coated with gold. A JEOL JSM-6610LV scanning electron microscope was used to visualize surface feature at $1000 \times$ magnification.

\subsection{Mechanical Assessment}

The mechanical properties of scaffolds were measured by the unconfined stressrelaxation test to obtain the equilibrium Young's modulus $\left(E_{Y}\right)$. Scaffolds $(n=4)$ were soaked in PBS overnight and placed in a testing chamber containing PBS at $37^{\circ} \mathrm{C}$ under tare load of $50 \mathrm{~N}$ for $30 \mathrm{~min}$. The stress-relaxation test at a ramp velocity of $2 \mu \mathrm{m} \cdot \mathrm{s}^{-1}$ was performed up to $50 \%$ strain using the Universal Testing Machine EZ-S (Shimadzu, Japan).

\subsection{Swelling Ratio}

The dry weight $\left(\mathrm{W}_{\mathrm{d}}\right)$ of scaffolds $(\mathrm{n}=4)$ was recorded, and the scaffolds were soaked in PBS solution ( $\mathrm{pH} 7.4$ ) at $37^{\circ} \mathrm{C}$ for $24 \mathrm{~h}$. The scaffolds were removed from PBS solution and excess liquid was blotted. The wet weight $\left(\mathrm{W}_{\mathrm{w}}\right)$ was recorded to calculate the swelling ratio, $\mathrm{S}$, as described in Equation (1).

$$
\mathrm{S}=\left(\mathrm{W}_{\mathrm{w}}-\mathrm{W}_{\mathrm{d}}\right) / \mathrm{W}_{\mathrm{d}}
$$

Change in swelling ratio per unit of time, the swelling rate $\left(S_{R}\right)$, was determined when swelling ratio linearly increased, as described in Equation (2), where $S_{t+\Delta t}$ represents the swelling ratio at time $t+\Delta t$ and $S_{t}$ represents swelling ratio at any time $t$.

$$
S_{R}=\left(S_{t+\Delta t}-S_{t}\right) / \Delta t
$$

\subsection{Cell Culture and Cell Seeding}

Chondrocytes (Lonza, Walkkersville, MD, USA) were expanded in growth medium (DMEM supplemented with $1 \times$ serum replacement, $10 \mathrm{mM}$ HEPES, $1 \%$ antibiotic-antimycotic solution) and maintained in a $5 \% \mathrm{CO}_{2}$ incubator at $37^{\circ} \mathrm{C}$, with medium changes every 3 days. Subculturing was performed using TrypLE ${ }^{\mathrm{TM}}$ Express Enzyme when cells reached 80\% confluency. Scaffolds $8 \mathrm{~mm}$ in diameter and $5 \mathrm{~mm}$ in thickness were placed in $15 \mathrm{~mL}$ conical tubes. Twenty $\mu \mathrm{L}$ of $2 \times 10^{5}$ cells was seeded on the scaffold. Cell-seeded constructs were kept in a $5 \% \mathrm{CO}_{2}$ incubator at $37^{\circ} \mathrm{C}$ for $3 \mathrm{~h}$ to allow cell absorption into the scaffolds. Then, $1 \mathrm{~mL}$ of additional growth medium was added. The constructs were returned to the incubator and continued to grow for 7 days with medium changes every 3 days.

\subsection{Assessment of Cell Distribution and Cytotoxicity of PVA/CMC Scaffolds}

At day 7 post-seeding, constructs were cut through the center and incubated in Invitrogen $^{\mathrm{TM}}$ LIVE/DEAD ${ }^{\circledR}$ viability/cytotoxicity assay solution for $30 \mathrm{~min}$ in the $5 \% \mathrm{CO}_{2}$ incubator at $37^{\circ} \mathrm{C}$. The concentration of the assay solution was as described in manufacturer's instructions: $2 \mathrm{mM}$ calcien-AM and $4 \mathrm{mM}$ ethidium homodimer-1. The assay 
solution was replaced by $2 \mathrm{~mL}$ of $1 \times$ PBS to remove excess dye for $30 \mathrm{~min}$. The constructs were visualized under a fluorescent microscope to determine living and dead cells at wavelengths of 485 and $530 \mathrm{~nm}$, respectively.

The cell viability assay was performed in a 96-well plate (cat. 167008, Thermo Fisher Scientific, MA, USA). Chondrocytes were seeded at 15,000 cells/well and cultured in $100 \mu \mathrm{L}$ growth medium for $24 \mathrm{~h}$ to allow cell attachment. After that, the medium was replaced with $100 \mu \mathrm{L}$ of the following solutions: (1) DMEM, (2) DMEM incubated with P5C1 scaffold extract, (3) DMEM incubated with P3C1 scaffold extract, and (4) 10\% DMSO in DMEM. The plate was incubated at $37^{\circ} \mathrm{C}, 5 \% \mathrm{CO}_{2}$ for $24 \mathrm{~h}$. Cell viability assay was performed using PrestoBlue $^{\mathrm{TM}}$ assay (Invitrogen, Carisbad, CA) following the manufacturer's instructions. The plate was kept at $37{ }^{\circ} \mathrm{C}$ in $5 \% \mathrm{CO}_{2}$ conditions for $40 \mathrm{~min}$. Absorbance was measured at $\lambda_{\text {ex }} 560 \mathrm{~nm}$ and $\lambda_{\text {em }} 590 \mathrm{~nm}$. Scaffold extracts were prepared according to the ISO 109935:2009 test for in vitro cytotoxicity. Scaffolds $(n=5)$ were incubated in $1 \mathrm{~mL}$ serum-free $\mathrm{DMEM}$ at $37^{\circ} \mathrm{C}, 5 \% \mathrm{CO}_{2}$, for $24 \mathrm{~h}$.

\subsection{Statistical Analysis}

Statistical analysis was performed using GraphPad Prism software (La Jolla, CA, USA). Data were expressed as average \pm standard error of $n=4-6$ per group. The differences in Young's modulus, swelling ratio, and cytotoxicity were evaluated using two-way ANOVA, followed by Tukey's post-test with $\alpha=0.05$ to consider statistical significance.

Supplementary Materials: The following are available online. Figure S1: Glass transition $\left(\mathrm{T}_{\mathrm{g}}\right)$, melting temperature $\left(\mathrm{T}_{\mathrm{m}}\right)$, and crystallinity $\left(\mathrm{T}_{\mathrm{c}}\right)$ of PVA/CMC scaffolds, analysed by the DSC technique. Figure S2: Young's modulus $(\mathrm{kPa})$ of the PVA/CMC scaffold without cell seeding. Figure S3: In vitro scaffold degradation of the PVA/CMC scaffolds in PBS solution. Figure S4: Maximum swelling ratio of scaffolds that did not progress to the freeze-drying step. Scaffolds were dried at $60{ }^{\circ} \mathrm{C}$ in a hot air oven for $48 \mathrm{~h}$ and soaked in PBS solution for $24 \mathrm{~h}$. Figure S5: Water content of scaffolds. Figure S6: Cell attachment. Non-coated wells were used as positive control for cell attachment. Figure S7: Solid-state NMR spectra of the P1C0 control group and the P3C1 group. Figure S8: Preparation of porous PVA/CMC scaffolds.

Author Contributions: J.N. and N.S. carried out the experiment. P.L. contributed to swelling behavior analysis; S.J. helped to draft the manuscript; S.H. contributed to funding acquisition; S.Y. contributed to data analysis, interpreted data, and drafted the manuscript. All authors have read and agreed to the published version of the manuscript.

Funding: This research was funded by Thailand Research Fund (Grant No. MRG6080058) and Ratchadapiseksompotch Fund (Grant No. RA60/116).

Institutional Review Board Statement: Not applicable.

Informed Consent Statement: Not applicable.

Data Availability Statement: The data presented in this study are available on request from the corresponding author.

Acknowledgments: We acknowledge the assistance and support of the Scientific and Technological Research Equipment Centre, Chulalongkorn University. We also acknowledge Wanpen Tachaboonyakiat for her help with polymer education, Manunya Okhawilai for assisting with DSC analysis and Truc Trúc Nguyễn Thanh for interpretation of NMR spectra.

Conflicts of Interest: The authors declare no conflict of interest.

Sample Availability: The sample of compounds are available from corresponding author.

\section{References}

1. Hunziker, E.B. Articular cartilage repair: Basic science and clinical progress. A review of the current status and prospects. Osteoarthr. Cartil. 2002, 10, 432-463. [CrossRef]

2. Mora, J.C.; Przkora, R.; Cruz-Almeida, Y. Knee osteoarthritis: Pathophysiology and current treatment modalities. J. Pain Res. 2018, 11, 2189-2196. [CrossRef] [PubMed] 
3. Romagnoli, C.; Brandi, M.L. Adipose mesenchymal stem cells in the field of bone tissue engineering. World J. Stem Cells 2014, 6, 144-152. [CrossRef] [PubMed]

4. Shin, Y.M.; Park, J.S.; Jeong, S.I.; An, S.J.; Gwon, H.J.; Lim, Y.M.; Nho, Y.C.; Kim, C.Y. Promotion of human mesenchymal stem cell differentiation on bioresorbable polycaprolactone/biphasic calcium phosphate composite scaffolds for bone tissue engineering. Biotechnol. Bioproc. E 2014, 19, 341-349. [CrossRef]

5. Dattola, E.; Parrotta, E.I.; Scalise, S.; Perozziello, G.; Limongi, T.; Candeloro, P.; Coluccio, M.L.; Maletta, C.; Bruno, L.; De Angelis, M.T.; et al. Development of 3D PVA scaffolds for cardiac tissue engineering and cell screening applications. RSC Adv. 2019, 9, 4246-4257. [CrossRef]

6. Wang, F.; Guo, G.P.; Ma, Q.Y.; Gu, M.F.; Wu, X.Y.; Sheng, S.J.; Wang, X.S. Investigation on the thermo-mechanical properties and thermal stability of polylactic acid tissue engineering scaffold material. J. Therm. Anal. Calorim. 2013, 113, 1113-1121. [CrossRef]

7. Zhu, J.M.; Marchant, R.E. Design properties of hydrogel tissue-engineering scaffolds. Expert Rev. Med. Devic. 2011, 8, 607-626. [CrossRef]

8. Song, X.; Zhu, C.H.; Fan, D.D.; Mi, Y.; Li, X.; Fu, R.Z.; Duan, Z.G.; Wang, Y.; Feng, R.R. A Novel Human-Like Collagen Hydrogel Scaffold with Porous Structure and Sponge-Like Properties. Polymers 2017, 9, 638. [CrossRef]

9. Yodmuang, S.; McNamara, S.L.; Nover, A.B.; Mandal, B.B.; Aganwal, M.; Kelly, T.A.N.; Chao, P.H.G.; Hung, C.; Kaplan, D.L.; Vunjak-Novakovic, G. Silk microfiber-reinforced silk hydrogel composites for functional cartilage tissue repair. Acta Biomater. 2015, 11, 27-36. [CrossRef]

10. Zhou, J.; Shu, Y.; Lu, S.H.; Li, J.J.; Sun, H.Y.; Tang, R.Y.; Duan, C.M.; Wang, Y.; Lin, Q.X.; Mou, Y.C.; et al. The Spatiotemporal Development of Intercalated Disk in Three-Dimensional Engineered Heart Tissues Based on Collagen/Matrigel Matrix. PLoS ONE 2013, 8, e81420. [CrossRef]

11. Martinez, A.; Blanco, M.D.; Davidenko, N.; Cameron, R.E. Tailoring chitosan/collagen scaffolds for tissue engineering: Effect of composition and different crosslinking agents on scaffold properties. Carbohyd. Polym. 2015, 132, 606-619. [CrossRef] [PubMed]

12. Miranda, D.G.; Malmonge, S.M.; Campos, D.M.; Attik, N.G.; Grosgogeat, B.; Gritsch, K. A chitosan-hyaluronic acid hydrogel scaffold for periodontal tissue engineering. J. Biomed. Mater. Res. B 2016, 104, 1691-1702. [CrossRef] [PubMed]

13. Iravani, S.; Varma, R.S. Plants and plant-based polymers as scaffolds for tissue engineering. Green Chem. 2019, $21,4839-4867$. [CrossRef]

14. Yu, Z.L.; Dhital, R.; Wang, W.; Sun, L.; Zeng, W.C.; Mustapha, A.; Lin, M.S. Development of multifunctional nanocomposites containing cellulose nanofibrils and soy proteins as food packaging materials. Food Packag. Shelf 2019, 21. [CrossRef]

15. Sunardi, S.; Febriani, N.M.; Junaidi, A.B. Preparation of Carboxymethyl Cellulose Produced from Purun Tikus (Eleocharis dulcis). In Proceedings of the 4th International Conference on Research, Implementation, and Education of Mathematics and Sciences (Icriems), Research and Education for Developing Scientific Attitude in Sciences and Mathematics, Yogyakarta, Indonesia, 15-16 May 2017.

16. Samsi, M.S.; Kamari, A.; Din, S.M.; Lazar, G. Synthesis, characterization and application of gelatin-carboxymethyl cellulose blend films for preservation of cherry tomatoes and grapes. J. Food Sci. Tech. Mys. 2019, 56, 3099-3108. [CrossRef]

17. Phan, C.M.; Walther, H.; Riederer, D.; Lau, C.; Lorenz, K.O.; Subbaraman, L.N.; Jones, L. Analysis of polyvinyl alcohol release from commercially available daily disposable contact lenses using an in vitro eye model. J. Biomed. Mater. Res. B 2019, 107, 1662-1668. [CrossRef]

18. Sakai, S.; Tsumura, M.; Inoue, M.; Koga, Y.; Fukano, K.; Taya, M. Polyvinyl alcohol-based hydrogel dressing gellable on-wound via a co-enzymatic reaction triggered by glucose in the wound exudate. J. Mater. Chem. B 2013, 1, 5067-5075. [CrossRef]

19. Figueiredo, K.C.S.; Alves, T.L.M.; Borges, C.P. Poly(vinyl alcohol) Films Crosslinked by Glutaraldehyde Under Mild Conditions. J. Appl. Polym. Sci. 2009, 111, 3074-3080. [CrossRef]

20. Tang, C.; Saquing, C.D.; Harding, J.R.; Khan, S.A. In Situ Cross-Linking of Electrospun Poly(vinyl alcohol) Nanofibers. Macromolecules 2010, 43, 630-637. [CrossRef]

21. Banerjee, S.; Siddiqui, L.; Bhattacharya, S.S.; Kaity, S.; Ghosh, A.; Chattopadhyay, P.; Pandey, A.; Singh, L. Interpenetrating polymer network (IPN) hydrogel microspheres for oral controlled release application. Int. J. Biol. Macromol. 2012, 50, 198-206. [CrossRef] [PubMed]

22. Rezaee, S.; Moghbeli, M.R. Crosslinked Electrospun Poly (Vinyl Alcohol) Nanofibers Coated by Antibacterial Copper Nanoparticles. Iran. J. Chem. Eng. 2014, 11, 45-58.

23. Wang, Y.H.; Hsieh, Y.L. Crosslinking of Polyvinyl Alcohol (PVA) Fibrous Membranes with Glutaraldehyde and PEG Diacylchloride. J. Appl. Polym. Sci. 2010, 116, 3249-3255. [CrossRef]

24. Rudra, R.; Kumar, V.; Kundu, P.P. Acid catalysed cross-linking of poly vinyl alcohol (PVA) by glutaraldehyde: Effect of crosslink density on the characteristics of PVA membranes used in single chambered microbial fuel cells. RSC Adv. 2015, 5, 83436-83447. [CrossRef]

25. More, S.M.; Kulkarni, R.V.; Sa, B.; Kayane, N.V. Glutaraldehyde-Crosslinked Poly(vinyl alcohol) Hydrogel Discs for the Controlled Release of Antidiabetic Drug. J. Appl. Polym. Sci. 2010, 116, 1732-1738. [CrossRef]

26. Buhus, G.; Popa, M.; Peptu, C.; Desbrieres, J. Hydrogels based on carboxymethylcellulose and poly (vinyl alcohol) for controlled loading and release of chloramphenicol. J. Optoelectron. Adv. Mater. 2007, 9, 3445-3453.

27. Ghorpade, V.S.; Dias, R.J.; Mali, K.K.; Mulla, S.I. Citric acid crosslinked carboxymethylcellulose-polyvinyl alcohol hydrogel films for extended release of water soluble basic drugs. J. Drug Deliv. Sci. Technol. 2019, 52, 421-430. [CrossRef] 
28. Shapiro, E.M.; Borthakur, A.; Kaufman, J.H.; Leigh, J.S.; Reddy, R. Water distribution patterns inside bovine articular cartilage as visualized by H-1 magnetic resonance imaging. Osteoarthr. Cartil. 2001, 9, 533-538. [CrossRef]

29. Shiguetomi-Medina, J.M.; Ramirez-GL, J.L.; Stodkilde-Jorgensen, H.; Moller-Madsen, B. Systematized water content calculation in cartilage using T1-mapping MR estimations: Design and validation of a mathematical model. J. Orthop. Traumatol. 2017, 18, 217-220. [CrossRef]

30. Kim, J.; Kim, D.H.; Lim, K.T.; Seonwoo, H.; Park, S.H.; Kim, Y.R.; Kim, Y.; Choung, Y.H.; Choung, P.H.; Chung, J.H. Charged Nanomatrices as Efficient Platforms for Modulating Cell Adhesion and Shape. Tissue Eng. Part C Methods 2012, 18, 913-923. [CrossRef]

31. Ferrari, M.; Cirisano, F.; Moran, M.C. Mammalian Cell Behavior on Hydrophobic Substrates: Influence of Surface Properties. Colloid Interfaces 2019, 3, 48. [CrossRef]

32. Webb, K.; Hlady, V.; Tresco, P.A. Relative importance of surface wettability and charged functional groups on NIH 3 T3 fibroblast attachment, spreading, and cytoskeletal organization. J. Biomed. Mater. Res. 1998, 41, 422-430. [CrossRef]

33. O’Brien, F.J. Biomaterials \& scaffolds for tissue engineering. Mater. Today 2011, 14, 88-95.

34. Bhardwaj, V.; Harit, G.; Kumar, S. Vineet Bhardwaj, Gargi Harit1, Sokindra Kumar2. Int. J. Drug Dev. Res. 2012, 4, 41-54.

35. Suo, H.; Zhang, D.; Yin, J.; Qian, J.; Wu, Z.L.; Fu, J. Interpenetrating polymer network hydrogels composed of chitosan and photocrosslinkable gelatin with enhanced mechanical properties for tissue engineering. Mater. Sci. Eng. C Mater. Biol. Appl. 2018, 92, 612-620. [CrossRef]

36. Tigli, R.S.; Gumusderelioglu, M. Evaluation of alginate-chitosan semi IPNs as cartilage scaffolds. J. Mater. Sci.-Mater. Med. 2009, 20, 699-709. [CrossRef]

37. Rios, P.D.; Skoumal, M.; Liu, J.; Youngblood, R.; Kniazeva, E.; Garcia, A.J.; Shea, L.D. Evaluation of encapsulating and microporous nondegradable hydrogel scaffold designs on islet engraftment in rodent models of diabetes. Biotechnol. Bioeng. 2018, 115, 23562364. [CrossRef]

38. Hobson, R. Glass Formation and Sub-Tg Transitions in Polymers: Influence of Carbon Chemistry. In Encyclopedia of Materials: Science and Technology, 2nd ed.; Buschow, K.H.J., Flemings, M.C., Kramer, E.J., Veyssière, P., Cahn, R.W., Ilschner, B., Mahajan, S., Eds.; Pergamon Press: Oxford, UK, 2001; pp. 3545-3550.

39. Koontz, E. Thermal Analysis of Glass. In Springer Handbook of Glass, 1st ed.; Musgraves, J.D., Hu, J., Calvez, L., Eds.; Springer International Publishing: Cham, Switzerland, 2019; pp. 853-878.

40. Parparita, E.; Cheaburu, C.N.; Vasile, C. Morphological, Thermal and Rheological Characterization of Polyvinyl Alcohol/Chitosan Blends. Cell Chem. Technol. 2012, 46, 571-581.

41. Schindler, A.; Doedt, M.; Gezgin, S.; Menzel, J.; Schmolzer, S. Identification of polymers by means of DSC, TG, STA and computer-assisted database search. J. Therm. Anal. Calorim. 2017, 129, 833-842. [CrossRef]

42. Jin, F.Z.; Hyon, S.H.; Iwata, H.; Tsutsumi, S. Crosslinking of poly(L-lactide) by gamma-irradiation. Macromol. Rapid Commun. 2002, 23, 909-912. [CrossRef]

43. Suhartini, M.; Mitomo, H.; Nagasawa, N.; Yoshii, F.; Kume, T. Radiation crosslinking of poly(butylene succinate) in the presence of low concentrations of trimethallyl isocyanurate and its properties. J. Appl. Polym. Sci. 2003, 88, 2238-2246. [CrossRef]

44. Jahangirian, H.; Azizi, S.; Rafiee-Moghaddam, R.; Baratvand, B.; Webster, T.J. Status of Plant Protein-Based Green Scaffolds for Regenerative Medicine Applications. Biomolecules 2019, 9, 619. [CrossRef] [PubMed]

45. Chowdhury, M.N.K.; Alam, A.K.M.M.; Dafader, N.C.; Haque, M.E.; Akhtar, F.; Ahmed, M.U.; Rashid, H.; Begum, R. Radiation processed hydrogel of poly (vinyl alcohol) with biodegradable polysaccharides. Bio-Med. Mater. Eng. 2006, 16, $223-228$.

46. Saini, R.K.; Bagri, L.P.; Bajpai, A.K. Nano-silver hydroxyapatite based antibacterial 3D scaffolds of gelatin/alginate/poly (vinyl alcohol) for bone tissue engineering applications. Colloid Surface B 2019, 177, 211-218. [CrossRef] [PubMed] 